\title{
Estimation and Bio-Availability of Toxic Metals between Soils and Plants
}

\author{
Al Saad Mohammed Ali, Hatem Abdel Moniem Ahmed*, Hanan Abd El-Azim Emara, \\ Muhammad Naeem Janjua, Nada Alhafez
}

\author{
Department of Forensic Chemistry, College of Forensic Sciences, Naïf Arab University for Security Sciences, \\ Riyadh, Saudi Arabia
}

Received: 25 October 2017

Accepted: 2 January 2018

\begin{abstract}
Heavy metals contamination of soil is one of the most alarming concerns in the debate about food security and food safety all over the world because it determines the possible composition of food and feeds at the root level of the food chain. Simultaneously, plants are important components of the ecosystem as they transfer elements from abiotic and biotic environments. The primary sources of elements from the environment to plants are air, water, and soil. The aim of this study was to determine the accumulation levels of trace toxic heavy metals in soils and plant samples in the garden of the Al-Nadwa-Riyadh area. Lead and cadmium were measured in the soil and plants by graphite atomic absorption spectrometry, while arsenic and mercury were measured using hydride generation atomic absorption spectrometry. Plant samples were digested by $8 \mathrm{ml}$ of nitric acid followed by $2 \mathrm{ml}$ hydrogen peroxide, while soil samples were digested by $6 \mathrm{ml}$ concentrated nitric acid followed by $2 \mathrm{ml}$ hydrofluoric acid and $2 \mathrm{ml}$ hydrogen peroxide. In soil samples, results presented here showed that levels of lead were within the set of all standards, while cadmium exceeds the limits of FAO and EC standards. Arsenic was found to be above the FAO standard but within the set of all other standards. On the contrary, mercury was investigated far above all the set standards. All levels of the heavy metals in all plant samples were below the maximum permissible limit standard values of FAO/WHO, except mercury. The results demonstrated that mean content of $\mathrm{Hg}$ uptake by the plants was higher than the contents of each trace metals under test.
\end{abstract}

Keywords: heavy metals, plant, soil, spectroscopy

\section{Introduction}

Soil and land contamination by heavy metals has become a serious environmental concern due to its potential adverse ecological effects. Although heavy

*e-mail: Hatemahmed29@nauss.edu.sa, Hatemahmed29@yahoo.com metals occur naturally at low concentrations in soils, they are considered soil contaminants due to their widespread occurrence, as well as their acute and chronic toxicity. The serious effects of heavy metals on soil biochemical properties are well documented [1].

Soil properties, i.e., mud content, organic substances, and $\mathrm{pH}$, mainly affect organic and biochemical properties [2]. Soils contaminated by heavy metals, such as $\mathrm{Ni}, \mathrm{Zn}$, $\mathrm{Cd}, \mathrm{Cu}$, and $\mathrm{Pb}$ have dramatically increased during the 
last decades ago due to the use of agricultural fertilizers and pesticides, municipal waste, mining, traffic, smelting, manufacturing, emissions, and industrial effluents [3]. However, some risk element, like arsenic (As), cadmium $(\mathrm{Cd})$, lead $(\mathrm{Pb})$, selenium $(\mathrm{Se})$, and methylated forms of mercury $(\mathrm{Hg})$ are considered one of the major sources of soil pollution [4]. These metals are considered not essential for plant growth because they do not perform any known physiological function in plants. Moreover, they are also reported to have no known biological importance in human biochemical or physiological functions [5]. Their consumption even at very low concentrations can be toxic to humans.

Other metals such as calcium (Ca), cobalt (Co), magnesium $(\mathrm{Mg})$, cupper $(\mathrm{Cu})$, iron $(\mathrm{Fe})$, manganese $(\mathrm{Mn})$, molybdenum (Mo), nickel (Ni), and zinc ( $\mathrm{Zn})$ are essential elements required for normal growth and metabolism of plants, and have also been reported to be of biological importance to human beings to maintain their optimal life activities. However, these elements can easily lead to poisoning when their concentrations rise above allowed limits or optimal values [6-9].

Accordingly, when concentration of heavy metals becomes more than standard or optimum levels in soil, they cause toxic effects in soil microorganisms, resulting in a change of population size, diversity, and overall activity of the soil microbial communities [10]. This indicates that heavy metal concentration in soil plays an important role in controlling metal bioavailability to plants. Ultimately, increasing heavy metal contents in the soil also increases the uptake of heavy metals by plants depending upon soil type, plant growth stages, and plant species [11].

For example, due to higher $\mathrm{Pb}$ concentrations in soil, some fundamental physiological activities of soil are reduced, which could affect plant quality, reduction of cell activities, and inhibition of plant growth, water absorption, and photosynthesis. Meanwhile, very low concentrations of lead $(\mathrm{Pb})$ in soil could lead toxic symptoms on dark green leaves, wilting of older leaves, brown short leaves, stunted foliage, and brown short roots [12-13].

Ingestion of vegetables and food commodities irrigated with waste or improperly treated water, or grown in soils contaminated with heavy metals present possible health risks to humans and wildlife. The uptake of heavy toxic metals from soils by plants at high concentrations leads to subsequent accumulation along the food chain and may result in a greater health risk [14]. Some important supplements in the human body are influenced by consumption of food contaminated with heavy metals, causing decreased immunity, intrauterine growth retardation, disabilities associated with malnutrition, and a high prevalence of upper gastrointestinal cancer rates [15]. The risk of transference of heavy metals from soil to plants and from plants to humans should be a matter of great concern [16]. Absorption of heavy metals by plant roots from soil (one of the major routes for the entrance of heavy metals into the food chain) and the following accumulation along the food chain is a potential threat to animal and human health, particularly crops [17].

Most studies have shown that the use of wastewater contaminated with heavy metals for irrigation over a long period of time increases the heavy metal contents of soils above the permissible limit [18]. Wastewater from the chemical industry and chemical laboratories is one of the most important sources of heavy metal contamination leading to the pollution of groundwater and agricultural soil. In recent years, factory wastewater was discharged into rivers, lakes, and coastal areas, resulting in serious pollution problems in the water environment and causing negative effects to the ecosystem and human life. This wastewater may contain numerous toxic and harmful substances in the form of heavy metals, petroleum, and chlorinated hydrocarbons, alkalis, various acids, dyes, and other chemicals such as pesticides, herbicides, and fertilizers, which change the physiochemical properties of water [19].

All these chemicals are quite harmful or even fatally poisonous to the aquatic ecosystem [20-21]. Heavy metals from mining locales may reach agricultural soils through leaching. Also, during the rainy season large quantities of tailings and waste containing heavy metals are carried by runoff to agricultural fields near mining sites, which leads to elevated levels of heavy metals in soils [22].

\section{Transfer Factor (TF)}

Transfer factor (TF) describes the amount of heavy metal transferred from the soil to the plant under equilibrium conditions [23-24]. Heavy metals from the soil are consumed by plant roots and then distributed in various plant tissues. Transfer of this heavy metal from soil to plant tissues is measured using the TF indicator, which measures the ratio of the concentration of a specific metal in plant tissue to the concentration of the same metal in soil - both represented by the same units. If the TF values are $\geq 1.0$ it shows a higher uptake of metal from soil by the plant, while lower values mean less absorption of the metal from the soil, and the plant can be used for consumption [25]. This theory assumes a linear relationship between the concentrations of a certain element in the plant with that in the soil:

$$
\mathrm{C}_{\text {Plant }}=\mathrm{a}+\mathrm{TFC}_{\text {Soil }}
$$

...where " $\mathrm{C}_{\text {plant }}$ " and " $\mathrm{C}_{\text {soil }}$ " are the concentrations of an element in plant and soil, respectively, and parameter " $a$ " is zero if the element enters the plant only from the soil. This linearity does not hold for essential elements (the contents of which are under strict metabolic control), but can hold for non-essential elements and pollutants.

This paper focusses on the study of accumulation of some heavy metals $(\mathrm{Pb}, \mathrm{Cd}, \mathrm{As}$, and $\mathrm{Hg})$ in some varieties of plants in Saudi Arabia that are irrigated with treated 
water in the Al-Nadwa Garden in Riyadh. Heavy metals were quantitatively determined by the atomic absorption spectroscopy (AAS) method. Selection of these metals was based upon their potential contribution in causing threats to various biotic and abiotic components of the environment [25].

\section{Materials and Methods}

\section{Collecting Plant and Soil Samples}

Twenty different types of ornamental plant along with their leaves and flowers were collected in acid-washed polyethylene bags according to the sampling procedures of Tony and Australian National Botanic Gardens (Table 1) [26-27]. In addition, 20 soil samples were collected in acid-washed polyethylene bags from different locations from a depth of approximately 10-30 cm under each plant and placed in plastic bottles according to the method of Zhang [28]. The plants and soils were collected randomly inside the premises of Al-Nadwa Garden.

\section{Plant and Soil Sample Treatments}

\section{Plant Sampling}

The collected plant samples were washed two to three times with tap water, and then again washed two to three times with distilled deionized water to remove dust particles, and were dried overnight in an oven at $95^{\circ} \mathrm{C}$. The dried samples were ground in an electrical grinder to make powder. The powdered plant samples were transferred to acid-washed and labeled polyethylene bags and stored until further analysis.

\section{Soil Sampling}

Collected soil samples were brought to the laboratory and mashed with the help of a pestle and mortar, and transferred to an acid-washed labeled china crucible. The crucibles along with the samples were dried in an electric oven at $105^{\circ} \mathrm{C}$ overnight. All the dried soil samples were passed through a fine sieve to separate the un-gradable stone residues. The sieved soil samples were ground in a grinder to make powder and stored in acid-washed polyethylene bags until further laboratory analysis.

\section{Digestion Methodology for Plant Samples}

Correctly weighed 0.250 grams of each sample were transferred to acid-washed PTFE vessels, and $8 \mathrm{ml}$ of reagent-grade nitric acid $(69 \%)$ was added to each vessel, followed by $2 \mathrm{ml}$ of $(35 \%)$ hydrogen peroxide. All vessels were tightly closed and loaded into a Milestones Ethos One microwave digestion system
Table 1. Names of plants.

\begin{tabular}{|c|c|}
\hline Plant Sample I.D & Name of Plant \\
\hline 1 & Cestrum nocturnum \\
\hline 2 & Rosa rubiginosa \\
\hline 3 & $\begin{array}{c}\text { Euonymus japonicus "Silver } \\
\text { king" }\end{array}$ \\
\hline 4 & Magnolia \\
\hline 5 & Dracaena fragrans \\
\hline 6 & Conocarpus erectus \\
\hline 7 & Jasmine \\
\hline 8 & Dracaena braunii \\
\hline 9 & Ficus benjamina \\
\hline 10 & Syngonium \\
\hline 11 & Dieffenbachia \\
\hline 12 & Peppermint. \\
\hline 13 & Scindapsus \\
\hline 14 & Dracaena fragrans \\
\hline 15 & Sphagneticola \\
\hline 16 & Petunia \\
\hline 17 & Malva parviflora \\
\hline 18 & Cordyline indivisa/australis \\
\hline 19 & Yucca \\
\hline 20 & Purple heart \\
\hline
\end{tabular}

[29-30]. The microwave digestion system was run as indicated below:

\begin{tabular}{|c|c|c|}
\hline Time $(\mathrm{t})$ & Temperature $\left({ }^{\circ} \mathrm{C}\right)$ & Watts (energy) \\
\hline 15 mints. & 180 & 1500 \\
\hline 20 mint (hold time) & 180 & 1500 \\
\hline
\end{tabular}

After the run was completed, all vessels in the system were allowed to cool for 10-15 minutes. The vessels were taken out and each digested sample was transferred to $50 \mathrm{ml}$ volumetric flasks. We added an appropriate volume of deionized distilled water to make the volume exactly $50 \mathrm{ml}$. Each sample was filtered through a $0.45 \mu$ PTFE filter and stored in properly labeled polyethylene bottles and refrigerated at $4^{\circ} \mathrm{C}$ until further analysis.

\section{Digestion Methodology for the Soil Samples}

Exactly 0.250 grams of soil were weighed from each soil sample and placed in PTFE vessels. Then we added $6 \mathrm{ml}$ reagent-grade concentrated nitric acid (69\%) followed by $2 \mathrm{ml}$ of (48\%) hydrofluoric acid and $2 \mathrm{ml}$ of (35\%) hydrogen peroxide and waited for 10-15 mins to complete the reaction. All vessels were tightly closed 
Table 2. Standard operating parameters of the elements analyzed in plants.

\begin{tabular}{|c|c|c|c|c|}
\hline Parameters & $\mathrm{Pb}$ & $\mathrm{Cd}$ & $\mathrm{As}$ & $\mathrm{Hg}$ \\
\hline Wavelength $(\mathrm{m})$ & 283.3 & 228.8 & 197.2 & 253.7 \\
\hline Slit Width $(\mathrm{nm})$ & 0.5 & 0.5 & 0.5 & 0.5 \\
\hline Lamp Current $(\mathrm{mA})$ & 10 & 4 & 10 & 4 \\
\hline Sensitivity $(\mathrm{mg} / \mathrm{kg}) \mathrm{At} 0.2 \mathrm{Abs}$ & 27 & 1.00 & 50 & 70 \\
\hline Detection Limit $(\mathrm{mg} / \mathrm{kg})$ & 0.002 & 0.00006 & 0.0028 & 0.002 \\
\hline Quantification Limit $(\mathrm{mg} / \mathrm{kg})$ & 0.006 & 0.00018 & 0.0084 & 0.006 \\
\hline Optimum Working Range $(\mathrm{mg} / \mathrm{kg})$ & $0.006-0.03$ & $0.00018-0.001$ & $0.0084-0.1$ & $0.006-0.03$ \\
\hline Instrument & GT-AAS & GT-AAS & HG-AAS & HG-AAS \\
\hline
\end{tabular}

Table 3. Standard operating parameters of the elements analyzed in soils.

\begin{tabular}{|c|c|c|c|c|}
\hline Parameters & $\mathrm{Pb}$ & $\mathrm{Cd}$ & $\mathrm{As}$ & $\mathrm{Hg}$ \\
\hline Wavelength $(\mathrm{m})$ & 283.3 & 228.8 & 197.2 & 253.7 \\
\hline Slit Width $(\mathrm{nm})$ & 0.5 & 0.5 & 0.5 & 0.5 \\
\hline Lamp Current $(\mathrm{mA})$ & 10 & 4 & 10 & 4 \\
\hline Sensitivity $(\mathrm{mg} / \mathrm{kg})$ At $0.2 \mathrm{Abs}$ & 27 & 1.00 & 50 & 70 \\
\hline Detection Limit $(\mathrm{mg} / \mathrm{kg})$ & 0.5 & 0.047 & 0.027 & 2.7 \\
\hline Quantification Limit $(\mathrm{mg} / \mathrm{kg})$ & 1.6 & 0.144 & 0.082 & 8.3 \\
\hline Optimum Working Range $(\mathrm{mg} / \mathrm{kg})$ & $1.6-2.5$ & $0.144-0.600$ & $0.08-0.25$ & $8.3-25$ \\
\hline Instrument & GTAAS & GTAAS & HGAAS & HGAAS \\
\hline
\end{tabular}

and loaded into the microwave digestion system [31-32], and the system was run as indicated previously. After the run was completed, the vessels were taken out and each digested sample was transferred to $50 \mathrm{ml}$ volumetric flasks, and the volume of each sample was adjusted accurately up to $50 \mathrm{ml}$ with deionized distilled water. Now each sample was filtered through a $0.45 \mu$ PTFE filter and stored in properly labeled polyethylene bottles until further analysis.

\section{Instrumentation}

We used a high-performance Ethos One microwave digestion system, a 240FS AA atomic absorption spectrometer from Agilent Technologies with (Graphite Furnace) GTA 120 “æ" "PSD” 120, a programmable sample dispenser, and argon carrier gas. The operating conditions during the analysis of heavy metals are listed in Tables 2-3 for plant and soil, respectively. Clear solutions of the digested samples were analyzed by graphite atomic absorption spectrometry (GTAAS) for $\mathrm{Pb}$ and $\mathrm{Cd}$ using argon gas, while As and $\mathrm{Hg}$ were analyzed by the hydride generation atomic absorption spectrometry (HG - AAS, AAS 240FS) method using flame atomic absorption spectrometry (FAAS) with air-acetylene (model: AAS 240FS), Agilent Technologies Company, USA, by the standard calibration technique. All measurements were run in triplicate for the samples and standard solutions and the results reported as the main \pm standard deviation. All the results were statistically significant at $\mathrm{P}<0.05$.

\section{Statistical Analysis}

The data were analyzed using Package for Social Science (SPSS) v. 20 statistical software (SPSS Inc., Chicago, IL, USA) after data were normalized by $\log$ transformation. Descriptive statistical parameters such as main and standard deviation (SD) were used to describe the heavy metal concentration in soils and plants, and differences were considered statistically significant with $p$ value $<0.05$. One sample test, Sig. (2-tailed) was used to determine the difference of the heavy metals concentrations in soils and plants at a significance level of $\mathrm{p}<0.05$.

\section{Results and Discussion}

Heavy metals may enter the human body through inhalation of polluted dust, contaminated soil used for irrigation, and food plants grown on metal-contaminated 
Table 4. Statistical description of the experimental results of soil samples.

\begin{tabular}{|c|c|c|c|c|}
\hline $\begin{array}{l}\text { Soil sample } \\
\text { number }\end{array}$ & $\begin{array}{c}\text { Mean conc. of } \\
\mathrm{Pb} \text { in } \mathrm{mg} / \mathrm{kg} \pm \mathrm{S} . \mathrm{D}\end{array}$ & $\begin{array}{c}\text { Mean conc. of } \\
\mathrm{Cd} \text { in } \mathrm{mg} / \mathrm{kg} \pm \mathrm{S} . \mathrm{D}\end{array}$ & $\begin{array}{c}\text { Mean conc. of } \\
\text { As in } \mathrm{mg} / \mathrm{kg} \pm \text { S.D }\end{array}$ & $\begin{array}{c}\text { Mean conc. of } \\
\mathrm{Hg} \text { in } \mathrm{mg} / \mathrm{kg} \pm \text { S.D }\end{array}$ \\
\hline 1 & $1.96 \pm 0.0004$ & $0.430 \pm 0.0010$ & $0.237 \pm 0.0015$ & $15.066 \pm 0.0004$ \\
\hline 2 & $1.92 \pm 0.0002$ & $0.422 \pm 0.0015$ & $0.2160 \pm 0.0031$ & $12.380 \pm 0.0003$ \\
\hline 3 & $2.10 \pm 0.0002$ & $0.438 \pm 0.0062$ & $0.2183 \pm 0.0021$ & $11.527 \pm 0.0003$ \\
\hline 4 & $1.95 \pm 0.0002$ & $0.437 \pm 0.0015$ & $0.2161 \pm 0.0021$ & $10.719 \pm 0.0011$ \\
\hline 5 & $1.92 \pm 0.0002$ & $0.465 \pm 0.0015$ & $0.1995 \pm 0.0010$ & $10.485 \pm 0.0043$ \\
\hline 6 & $2.20 \pm 0.0001$ & $0.460 \pm 0.0010$ & $0.2183 \pm 0.0025$ & $9.726 \pm 0.0003$ \\
\hline 7 & $1.60 \pm 0.0002$ & $0.462 \pm 0.0015$ & $0.2086 \pm 0.0020$ & $10.331 \pm 0.0002$ \\
\hline 8 & $1.60 \pm 0.0001$ & $0.473 \pm 0.0015$ & $0.2134 \pm 0.0021$ & $12.077 \pm 0.0005$ \\
\hline 9 & $1.68 \pm 0.0223$ & $0.498 \pm 0.0020$ & $0.2172 \pm 0.0020$ & $11.254 \pm 0.0004$ \\
\hline 10 & $1.79 \pm 0.0002$ & $0.494 \pm 0.0020$ & $0.2090 \pm 0.0020$ & $11.149 \pm 0.0003$ \\
\hline 11 & $1.64 \pm 0.0015$ & $0.507 \pm 0.0015$ & $0.1951 \pm 0.0010$ & $9.901 \pm 0.0005$ \\
\hline 12 & $1.60 \pm 0.0001$ & $0.501 \pm 0.0015$ & $0.1951 \pm 0.0012$ & $10.425 \pm 0.0004$ \\
\hline 13 & $1.61 \pm 0.0012$ & $0.515 \pm 0.0015$ & $0.1971 \pm 0.0020$ & $10.984 \pm 0.0003$ \\
\hline 14 & $1.60 \pm 0.0002$ & $0.508 \pm 0.0015$ & $0.1892 \pm 0.0015$ & $11.112 \pm 0.0004$ \\
\hline 15 & * not detected & $0.509 \pm 0.0021$ & $0.2120 \pm 0.0015$ & $10.885 \pm 0.0003$ \\
\hline 16 & * not detected & $0.519 \pm 0.0015$ & $0.1830 \pm 0.0010$ & $15.151 \pm 0.0005$ \\
\hline 17 & $1.78 \pm 0.0002$ & $0.516 \pm 0.0025$ & $0.1971 \pm 0.0021$ & $12.929 \pm 0.0004$ \\
\hline 18 & $1.97 \pm 0.0003$ & $0.532 \pm 0.0010$ & $0.2261 \pm 0.0010$ & $13.968 \pm 0.0009$ \\
\hline 19 & $1.66 \pm 0.0001$ & $0.553 \pm 0.0015$ & $0.2102 \pm 0.0010$ & $13.100 \pm 0.0007$ \\
\hline 20 & * not detected & $0.542 \pm 0.0010$ & $0.2331 \pm 0.0015$ & $12.099 \pm 0.0005$ \\
\hline Min. & 1.60 & 0.422 & 0.1830 & 9.726 \\
\hline Max. & 2.20 & 0.553 & 0.2370 & 15.151 \\
\hline Mean & 1.76 & 0.49 & 0.21 & 11.76 \\
\hline STD & 0.0015 & 0.0018 & 0.0017 & 0.0007 \\
\hline Mean \pm STD & $1.76 \pm 0.0015$ & $0.49 \pm 0.0018$ & $0.21 \pm 0.0017$ & $11.76 \pm 0.0007$ \\
\hline
\end{tabular}

*N/D (not detected)

soil [33]. Despite the poor bioavailability of heavy metals in soil, the plants may have a high ability to accumulate them in their different parts [34]. So, analyses of wild edible plants are important to identify and measure the

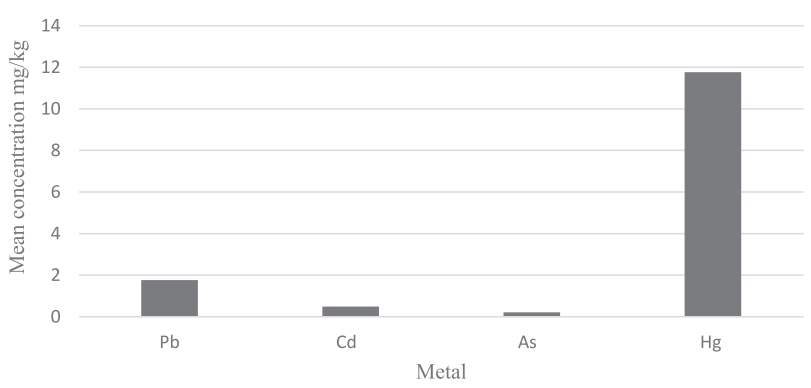

Fig. 1. Mean concentrations of metals in soils. level of toxic metals. The present study was carried out to evaluate the level of heavy metal contamination in the various types of soil and plants in the garden of Al-Nadwa. In all soil samples, the results showed the presence of $\mathrm{Cd}, \mathrm{As}$, and $\mathrm{Hg}$, but $\mathrm{Pb}$ was not detected at the sites $(15,16,22)$.

The results of heavy metal concentrations in soils are given in Table 4 and Fig. 1. Lead as a soil contaminant is a widespread issue; it accumulates with age in bones, the aorta, kidneys, liver, and spleen. The probability of lead $(\mathrm{Pb})$ entrance in the human body by food is $65 \%$, by water $20 \%$, and by air $15 \%$.

The calculated range of the concentrations of $\mathrm{Pb}$ in soils was $1.6-2.2 \mathrm{mg} / \mathrm{kg}$, except samples 15,16 , and 20, which have fallen below the detection limit of the instrument. All were within the set standards of FAO/WHO and Ling-Zhi [35-36], Austria, Germany, 
Table 5. Permissible limits of metals in soil by different standards.

\begin{tabular}{|c|c|c|c|c|}
\hline Standards/Guidelines & $\begin{array}{c}\mathrm{Pb} \\
\mathrm{mg} / \mathrm{kg}\end{array}$ & $\begin{array}{c}\mathrm{Cd} \\
\mathrm{mg} / \mathrm{kg}\end{array}$ & $\begin{array}{c}\mathrm{As} \\
\mathrm{mg} / \mathrm{kg}\end{array}$ & $\begin{array}{c}\mathrm{Hg} \\
\mathrm{mg} / \mathrm{kg}\end{array}$ \\
\hline FAO/WHO & $90-400$ & - & - & 1.0 \\
\hline EC & 0.30 & 0.003 & 20 & - \\
\hline United States & $50-300$ & 1.6 & 14 & 0.5 \\
\hline Poland & $70-150$ & $1-3$ & 30 & 5 \\
\hline Germany & 100 & $1.5-3$ & 20 & 2 \\
\hline Austria & 100 & 5 & 50 & 5 \\
\hline
\end{tabular}

Poland, the United States, and the European Council for European communities standards (Table 5) [26, 28].
Concentrations of $\mathrm{Cd}$ in soils $(0.422-0.553 \mathrm{mg} / \mathrm{kg})$ were far above the FAO/WHO and EC standards and within the set standards of Austria, Germany, Poland, and the USA, while the concentrations of As in soils $(0.183-2.37 \mathrm{mg} / \mathrm{kg})$ were far above the $\mathrm{FAO} / \mathrm{WHO}$ standard and within the set standards of Austria, Germany, Poland, the USA, and EC (Table 5). In contrast, the concentrations of $\mathrm{Hg}$ analyzed in soils were by far above the FAO/WHO, Austria, Germany, Poland, USA, and EC set standards (Table 5). The order of the metals concentrations in soils (mean \pm STD) is: $\mathrm{Hg}(11.76 \pm 0.0007)>\mathrm{Pb}(1.76 \pm 0.0015)>\mathrm{Cd}(0.49 \pm 0.0018)$ $>$ As $(0.21 \pm 0.0017)$.

The reason for this extremity in values might be due to the addition of civic wastes and effluents as the sewage of the factories and universities near a garden.

Table 6. Statistical description of the experimental results of plant samples.

\begin{tabular}{|c|c|c|c|c|}
\hline $\begin{array}{c}\text { Plant sample } \\
\text { number }\end{array}$ & $\begin{array}{c}\text { Mean conc. of } \\
\mathrm{Pb} \text { in } \mathrm{mg} / \mathrm{kg} \pm \mathrm{S} . \mathrm{D}\end{array}$ & $\begin{array}{c}\text { Mean conc. of } \\
\mathrm{Cd} \text { in } \mathrm{mg} / \mathrm{kg} \pm \mathrm{S} . \mathrm{D}\end{array}$ & $\begin{array}{c}\text { Mean conc. of } \\
\text { As in } \mathrm{mg} / \mathrm{kg} \pm \text { S.D }\end{array}$ & $\begin{array}{c}\text { Mean conc. of } \\
\mathrm{Hg} \text { in } \mathrm{mg} / \mathrm{kg} \pm \mathrm{S} . \mathrm{D}\end{array}$ \\
\hline 1 & $0.006 \pm 0.0056$ & $0.0006 \pm 0.0105$ & $0.01 \pm 0.0026$ & $2.51 \pm 0.0002$ \\
\hline 2 & $0.100 \pm 0.0013$ & $0.0005 \pm 0.0033$ & $0.01 \pm 0.0009$ & $2.44 \pm 0.0003$ \\
\hline 3 & $0.007 \pm 0.0005$ & $0.0004 \pm 0.0008$ & $0.01 \pm 0.002$ & $2.57 \pm 0.0003$ \\
\hline 4 & $0.006 \pm 0.0097$ & $0.0006 \pm 0.0038$ & $0.02 \pm 0.0160$ & $3.19 \pm 0.0010$ \\
\hline 5 & $0.006 \pm 0.0024$ & $0.0010 \pm 0.0024$ & $0.01 \pm 0.0044$ & $3.04 \pm 0.0010$ \\
\hline 6 & $0.006 \pm 0.0023$ & $0.0006 \pm 0.0041$ & $0.01 \pm 0.0063$ & $2.94 \pm 0.0003$ \\
\hline 7 & * not detected & $0.0006 \pm 0.0022$ & $0.02 \pm 0.0030$ & $3.13 \pm 0.0008$ \\
\hline 8 & * not detected & $0.0006 \pm 0.0034$ & $0.01 \pm 0.0024$ & $2.66 \pm 0.0006$ \\
\hline 9 & $0.007 \pm 0.0011$ & $0.0006 \pm 0.0019$ & $0.03 \pm 0.0019$ & $3.55 \pm 0.0001$ \\
\hline 10 & $0.007 \pm 0.0025$ & $0.0008 \pm 0.0018$ & $0.01 \pm 0.0020$ & $2.43 \pm 0.0004$ \\
\hline 11 & $0.0110 \pm 0.0010$ & $0.0007 \pm 0.0016$ & $0.02 \pm 0.0012$ & $3.12 \pm 0.0005$ \\
\hline 12 & * not detected & $0.0006 \pm 0.0004$ & $0.02 \pm 0.0028$ & $2.62 \pm 0.0003$ \\
\hline 13 & $0.007 \pm 0.0031$ & $0.0005 \pm 0.0016$ & $0.01 \pm 0.0022$ & $2.53 \pm 0.0020$ \\
\hline 14 & $0.007 \pm 0.0053$ & $0.0005 \pm 0.0016$ & $0.01 \pm 0.002$ & $3.09 \pm 0.0002$ \\
\hline 15 & $0.01 \pm 0.0007$ & $0.0008 \pm 0.0020$ & $0.02 \pm 0.0020$ & $2.66 \pm 0.0001$ \\
\hline 16 & * not detected & $0.0005 \pm 0.0044$ & $0.01 \pm 0.0023$ & $2.23 \pm 0.0005$ \\
\hline 17 & $0.008 \pm 0.0013$ & $0.0008 \pm 0.0045$ & $0.03 \pm 0.0016$ & $2.51 \pm 0.0008$ \\
\hline 18 & $0.01 \pm 0.0044$ & $0.0005 \pm 0.0073$ & * not detected & * not detected \\
\hline 19 & $0.010 \pm 0.0580$ & $0.0008 \pm 0.0011$ & $0.02 \pm 0.0030$ & $3.22 \pm 0.0001$ \\
\hline 20 & $0.01 \pm 0.0150$ & $0.0008 \pm 0.0074$ & $0.02 \pm 0.0024$ & $3.76 \pm 0.0033$ \\
\hline Min. & 0.006 & 0.0004 & 0.008 & 2.23 \\
\hline Max. & 0.100 & 0.001 & 0.027 & 3.76 \\
\hline Mean & 0.012 & 0.0006 & 0.03 & 2.7 \\
\hline STD & 0.006 & 0.003 & 0.003 & 0.001 \\
\hline Mean \pm STD & $0.012 \pm 0.01$ & $0.0006 \pm 0.003$ & $0.015 \pm 0.003$ & $2.7 \pm 0.001$ \\
\hline
\end{tabular}

*ND (Not Detected) 


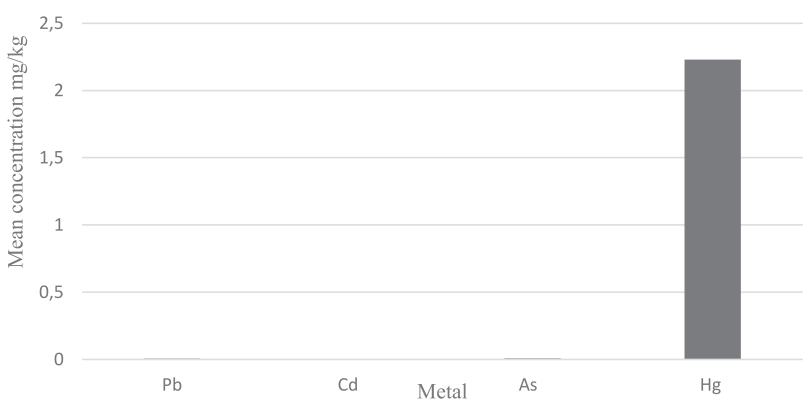

Fig. 2. Mean concentrations of metals in plants.

This agrees with the studies reporting that the level of heavy metals increasing in the soils due to the discharge of laboratories and industrial effluents and civic pollution of various kinds [37]. This is, in turn, deteriorating the soil and plant quality, making it unsuitable for both aquatic and human life. Mercury could be present in the soil in different forms. It dissolves as a free ion or soluble complex and is nonspecifically adsorbed by restricting fundamentally due to electrostatic forces, chelating potential, and precipitated as sulphides, carbonates, hydroxides, and phosphate. The results of this study showed that the averaged $\mathrm{Hg}$ concentration $(11.76 \mathrm{mg} / \mathrm{kg}$ ) was higher than its background $(0.065 \mathrm{mg} / \mathrm{kg})$ [38].

The results demonstrated that all the trace metals under examination were seen to be absorbed by all plants, but $\mathrm{Pb}, \mathrm{As}$, and $\mathrm{Hg}$ were not detected in samples (7, 8, 12, and 16), 18 and 18, respectively (Table 6, Fig. 2). Mercury was absorbed by plants as the sequence purple heart $>(3.76 \pm 0.0033)>$ Ficus Benjamina $(3.55 \pm 0.0001)$ $>$ Magnolia $(3.19 \pm 0.0010)>$ Jasmine $(3.13 \pm 0.0008)>$ Dieffenbachia (3.12 \pm 0.0005$)$, while the second was $\mathrm{Pb}$, third was $\mathrm{As}$, and fourth was $\mathrm{Cd}$ as the following $(0.01 \pm 0.01)$ absorbed by Rosa Rubiginosa, $(0.01 \pm 0.01)$ absorbed by Rosa Rubiginosa, $(0.100 \pm 0.0013)$ absorbed by Rosa Rubiginosa, $(0.03 \pm 0.0019)$ absorbed by Ficus Benjamina, and $(0.0010 \pm 0.0024)$ absorbed by Dracaena Fragrans (Table 6, Fig. 2).

The results showed that in the soil samples the mean concentrations $(\mathrm{mg} / \mathrm{kg})$ of $\mathrm{Pb}, \mathrm{Cd}, \mathrm{As}$, and $\mathrm{Hg}$ are, respectively: $1.76 \pm 0.0015, \quad 0.49 \pm 0.0018, \quad 0.21 \pm 0.0017$, and $11.76 \pm 0.0007$. The average concentrations of plants from (1-20) are, respectively: $0.012 \pm 0.01,0.0006 \pm 0.003$,

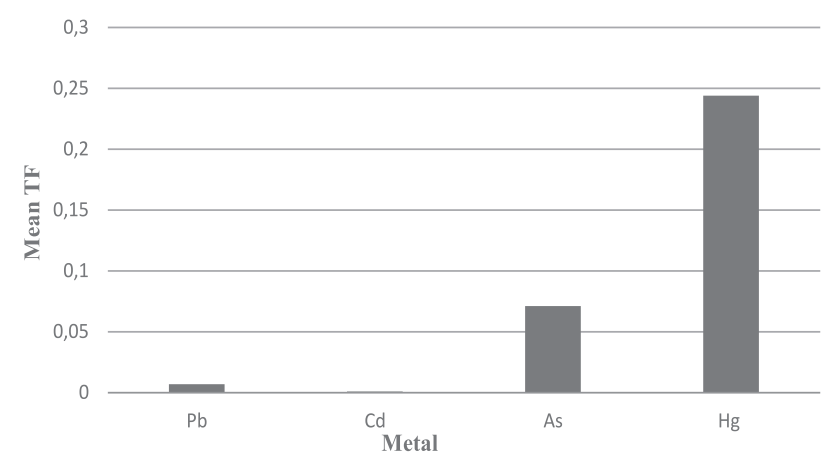

Fig. 3. Mean concentrations of TF plant to soil.
Table 7. Translocation factor of metals from plant to soil.

\begin{tabular}{|c|c|c|c|c|}
\hline $\begin{array}{c}\text { Plant sample } \\
\text { number }\end{array}$ & Lead & Cadmium & Arsenic & Mercury \\
\hline 1 & 0.003 & 0.001 & 0.042 & 0.167 \\
\hline 2 & 0.052 & 0.001 & 0.032 & 0.197 \\
\hline 3 & 0.003 & 0.001 & 0.041 & 0.223 \\
\hline 4 & 0.003 & 0.001 & 0.093 & 0.297 \\
\hline 5 & 0.003 & 0.002 & 0.065 & 0.290 \\
\hline 6 & 0.003 & 0.001 & 0.050 & 0.302 \\
\hline 7 & 0.003 & 0.001 & 0.101 & 0.303 \\
\hline 8 & 0.003 & 0.001 & 0.052 & 0.220 \\
\hline 9 & 0.004 & 0.001 & 0.115 & 0.315 \\
\hline 10 & 0.004 & 0.002 & 0.067 & 0.218 \\
\hline 11 & 0.007 & 0.001 & 0.103 & 0.316 \\
\hline 12 & 0.003 & 0.001 & 0.077 & 0.251 \\
\hline 13 & 0.004 & 0.001 & 0.051 & 0.230 \\
\hline 14 & 0.004 & 0.001 & 0.048 & 0.278 \\
\hline 15 & 0.006 & 0.002 & 0.094 & 0.244 \\
\hline 16 & 0.003 & 0.001 & 0.060 & 0.147 \\
\hline 17 & 0.004 & 0.002 & 0.137 & 0.194 \\
\hline 18 & 0.005 & 0.001 & 0.027 & 0.127 \\
\hline 19 & 0.006 & 0.001 & 0.086 & 0.245 \\
\hline 20 & 0.011 & 0.001 & 0.077 & 0.311 \\
\hline Average TF & 0.007 & 0.001 & 0.071 & 0.244 \\
\hline
\end{tabular}

$0.015 \pm 0.003$, and $2.7 \pm 0.001$ for $\mathrm{Pb}, \mathrm{Cd}$, As, and $\mathrm{Hg}$.

A study by Brian divided some metals into less, medium, and high potential to be accumulated in plants: $\mathrm{As}>\mathrm{Pb}>\mathrm{Hg}$ are the metals showing medium accumulation with $\mathrm{TF}=0.01-1.00$, the current study showed that potential to be accumulated in plants: $\mathrm{Hg}>\mathrm{As}>\mathrm{Pb}$ are the metals showed medium accumulation with $\mathrm{TF}=0.007-0.241$ (Table 7) [39]. In the case of $\mathrm{Cd}$, according to Brian, it was one of the elements intensively accumulated in plant bodies with $\mathrm{TF}=1.00-10.00$ (Table 7), which does not agree with the current study where TF of $\mathrm{Cd}$ were 0.001 , which may due to $\mathrm{Cd}$ being absorbed by the plants, then accumulating in different tissues (Table 6, Fig. 3).

In our present study, As, which showed medium content in soil under examination, recorded low amounts in plants. This might be due to a higher $\mathrm{pH}$, and the accessibility of As in solution form is less, which hiders the soil-plant transfer. All mean content of the heavy metals in all plant samples fall below the maximum permissible limit standard values except $\mathrm{Hg}$, (Table 8). This study showed that the mean contents of $\mathrm{Hg}(2.7 \pm 0.001)$ absorbed by the plants are higher than the contents of each trace metal under test. 
Table 8. Permissible limit values of the metals in plants by different standards.

\begin{tabular}{|c|c|c|c|c|c|}
\hline & Type of plant & $\mathrm{Pb}(\mathrm{mg} / \mathrm{kg})$ & $\mathrm{Cd}(\mathrm{mg} / \mathrm{kg})$ & $\mathrm{As}(\mathrm{mg} / \mathrm{kg})$ & $\mathrm{Hg}(\mathrm{mg} / \mathrm{kg})$ \\
\hline FAO/WHO, 1999 & leafy vegetables & 0.20 & 0.10 & 0.10 & 0.030 \\
\hline FAO/WHO, 2001 & vegetables & 0.30 & 0.20 & 0.43 & 0.03 \\
\hline
\end{tabular}

Cadmium is absorbed by all the plants almost equally by the 12 plants $(0.0006 \pm 0.004-0.0008 \pm 0.003)$, while $\mathrm{Pb}$ was the second metal absorbed by the five vegetables $(0.0 .007 \pm 0.0025)$. In the current study, TF of metals from soil to plant was $(0.007,0.001,0.071$ and 0.244$)$ for $\mathrm{Pb}, \mathrm{Cd}$, As and $\mathrm{Hg}$, respectively (Table 8, Fig. 3). That was to say with a sequence of decreasing TF values: $\mathrm{Hg}$ As $\mathrm{Pb} \mathrm{Cd}$.

The higher the value of transfer factor, the more element would be accumulated by plants. Mercury is the element with the highest TF values, which agrees with Yang, who reported a sequence of decreasing TF values as: $\mathrm{Ni}>\mathrm{Hg}>\mathrm{Zn}>\mathrm{Pb}>\mathrm{Cr}=\mathrm{Cd}>\mathrm{Cu}>\mathrm{Mn}$. $\mathrm{Hg}$ can be generalized for plants in the Rudna mine area [40]. The heavy metals $\mathrm{Hg}$ and As have greater soil-plant transfer rates than $\mathrm{Pb}$ and $\mathrm{Cd}$ (Table 7). The plants under test accumulate $\mathrm{Hg}$ in the following decreasing order: 0.316> $0.315>0.311>0.303>0.302>0.297>0.29>0.278>0.251>$ $0.245>0.244>0.23>0.223>0.22>0.218>0.197>0.194>$ $0.167>0.147>0.127$.

All the plants that can accumulate arsenic, cadmium, and lead are the least to be accumulated by all the plants. Gaile and Klavins stated that the lowest values of transfer factor for some plants grown in soils with the highest contamination levels of trace metals and with the addition of a solution of humic substances by that affirming intensity of metal sorption processes in soil connected with the presence of organic matter [41]. Plants and their soil samples do not accumulate metals equally. The accumulation and distribution were dependent on environmental factors [42].

Various studies explained that the absorbable availabilities of metals are not the only influencing factors for the bio-transfer of trace metals but also the plant species tendency to uptake a certain element from the soil [43-44].

\section{Plant Correlation Analysis}

Correlation analysis was carried out for trace heavy metals concentrations and plant associations in order to understand the significance $(\mathrm{p}=0.05, \mathrm{p}<0.05)$ of the association between metals and plants. The Pearson correlation coefficient matrix for trace heavy metals $(\mathrm{Pb}, \mathrm{Cd}, \mathrm{AS}$, and $\mathrm{Hg}$ ) and plant samples is presented in Table 9. The analysis of the interrelationship between the heavy metals and plants offers remarkable information on free ion availability. The computed statistical results showed that $\mathrm{Hg}$ has significant positive correlation with As $(r=0.461)$.

Mercury has moderate insignificant positive correlation with $\mathrm{Cd}(\mathrm{r}=0.341)$ and insignificant negative correlation with $\mathrm{Pb}(\mathrm{r}=-0.091)$. The negative correlation values show that as one variable increases in value, the second decreases. $50 \%$ of the metals are positively correlated (except for $\mathrm{Pb}-\mathrm{Cd}, \mathrm{Pb}-\mathrm{As}$, and $\mathrm{Pb}-\mathrm{Hg}$ ).

Table 9. Pearson correlations of trace heavy metals with vegetables.

\begin{tabular}{|c|c|c|c|c|c|}
\hline & & $\mathrm{Pb}$ & $\mathrm{Cd}$ & As & $\mathrm{Hg}$ \\
\hline \multirow{3}{*}{$\mathrm{Pb}$} & Pearson Correlation & 1 & 0.191 & 0.156 & 0.091 \\
\hline & Sig. (2-tailed) & & 0.421 & 0.511 & 0.702 \\
\hline & $\mathrm{N}$ & 20 & 20 & 20 & 20 \\
\hline \multirow{3}{*}{$\mathrm{Cd}$} & Pearson Correlation & 0.191 & 1 & 0.347 & 0.341 \\
\hline & Sig. (2-tailed) & 0.421 & & 0.133 & 0.142 \\
\hline & $\mathrm{N}$ & 20 & 20 & 20 & 20 \\
\hline \multirow{3}{*}{ As } & Pearson Correlation & 0.156 & 0.347 & 1 & $0.461^{*}$ \\
\hline & Sig. (2-tailed) & 0.511 & 0.133 & & 0.041 \\
\hline & $\mathrm{N}$ & 20 & 20 & 20 & 20 \\
\hline \multirow{3}{*}{$\mathrm{Hg}$} & Pearson Correlation & 0.091 & 0.341 & $0.461^{*}$ & 1 \\
\hline & Sig. (2-tailed) & 0.702 & 0.142 & 0.041 & \\
\hline & $\mathrm{N}$ & 20 & 20 & 20 & 20 \\
\hline
\end{tabular}

* Correlation is significant at the 0.05 level (2-tailed). 
The positive linear relationship of $\mathrm{Cd}-\mathrm{As}$ and $\mathrm{Cd}-\mathrm{Hg}$ ) was weak. Just $\mathrm{Hg}$ and $\mathrm{As}$ are respectably moderately associated with each other because both may have the normal sources or might be affected by the same agents. The basic sources of such contamination could either be the cultivating locals irrigated with dirtied water or atmospheric deposition of these metals because of vehicle contamination or sources of soil formation.

\section{Conclusion}

Concentrations of trace heavy metals in our studied soil samples show that $\mathrm{Pb}$ was within the set of all standards, while cadmium exceeded that of FAO/WHO and EC, but fell within all other standards (Ling-Zhi, Austria, Germany, Poland, USA). Arsenic was by far the within FAO/WHO limits, but within the set of all other standards. On the contrary, mercury was far above all the set standards (Table 6).

The mean content of all heavy metals in all our tested plant samples was below the maximum permissible standard values except for $\mathrm{Hg}$, which was above the standard limits set by FAO/WHO (Table 5). The detection of this toxic metal in our tested plant samples clearly indicates a persistent exposure of plants to soil contaminated with abnormally high concentrations of $\mathrm{Hg}$. Consumption of such contaminated edible plants for prolonged durations causes the accumulation of this highly neurotoxic substance in the human body, posing a serious health hazard to humans as well as animals.

Based on the results of this study, it is highly recommended that concerned authorities should carry out routine screening of soil as well as crops for the presence of toxic heavy metals.

\section{Acknowledgements}

The authors are thankful to the president of Naif Arab University for Security Sciences, the College of Forensic Sciences, and the Department of Forensic Chemistry for providing us with full support for this study.

\section{Conflict of Interest}

The authors declare no conflict of interest.

\section{References}

1. ADAMCOVA D., VAVERKOVA M. D., BARTON S., HAVLICEK Z., BROUSKOVA E. Soil contamination in landfills: a case study of a landfill in Czech Republic. Solid Earth. 7, 239, 2016.

2. ILKNURL G. Effects of Spent Mushroom Compost on Physicochemical Properties of Degraded Soil. Solid Earth Discuss. 2016, 2016
3. CHIBUIKE G.U., OBIORA S.C. Heavy Metal Polluted Soils: Effect on plants and bioremediation methods, Appl. Environ. Soil Sci. 2014.

4. MORGAN R. Soil, heavy metals, and human health, in: Soils and human health, edited by: BREVIK E. C. and BURGESS L. C., BOCA RATON F.L., USA, CRC Press. 59, 2013.

5. BELYAEVA E.A., SOKOLOVA T.V., EMELYANOVA L.V., ZASKHAROVA I.O. mitochondrial electron transport chain in heavy metal-induced neurotoxicity: effects of cadmium, mercury, and copper. Scientific World J. 136, 2012.

6. KARACA A., CETIN S.C., TURGAY O.C., KIZILKAYA Z.R. Effects of Heavy Metals on Soil Enzyme Activities. In: I. Sherameti and A. Varma (Ed), Soil Heavy Metals, Soil Biology, Heidelberg. 19, 237, 2010.

7. PAULA B.T., CLEMENT G., ANITA K .P, DWAYNE J.S Heavy Metals Toxicity and the Environment. Molecular, Clinical and Environmental Toxicology. 133, 2014.

8. BHATTACHARYA S., GUPTA K., DEBNATH S., GHOSH U. C., CHATTOPADHYAY D., MUKHOPADHYAY A. Arsenic bioaccumulation in rice and edible plants and subsequent transmission through food chain in Bengal basin: a review of the perspectives for environmental health, Toxicol. Environ. Chem. 94, 429, 2012.

9. RASCIO N., IZZO F.N. Heavy metal hyper accumulating plants: How and why do they do it? And what makes them so interesting? Plant Science. 180, 169, 2011.

10. 1SINGH J., KALAMDHAD A.S. Effects of Heavy Metals on Soil, Plants, Human Health and Aquatic Life. Int. J. Res. Chem. Environ. 1 (2), 15-21, 2011.

11. AFZAL S., ABDUL N., NAZEEF U., ALI R., MUHAMMAD A., MUHAMMAD Z., MUHAMMAD S. K. Comparative Study of Heavy Metals in Soil and Selected Medicinal Plants. Journal of Chemistry. 5, 2013.

12. BHATTACHARYYA P., CHAKRABARTI K., CHAKRABORTY A., TRIPATHY S., POWELL M.A. Fractionation and bioavailability of $\mathrm{Pb}$ in municipal solid waste compost and $\mathrm{Pb}$ uptake by rice straw and grain under submerged condition in amended soil. Geosciences Journal. 12, (1), 41, 2008.

13. ESAWY K.M., ADEL M.G. Effect of polluted water on soil and plant contamination by heavy metals in El-Mahla El-Kobra, Egypt. Solid Earth. 7, 703, 2016.

14. JORDAO C.P., NASCENTES C.C., CECON P.R., FONTES R.L.F., PEREIRA J.L. Heavy metal availability in soil amended with composted urban solid wastes. Environmental Monitoring and Assessment. 112, 309, 2006.

15. KHAN S., CAO Q., ZHENG Y.M., HUANG Y.Z., ZHU Y.G. Health risks of heavy metals in contaminated soils and food crops irrigated with wastewater in Beijing, China. Environmental Pollution. 152, 686, 2008.

16. FLORESCUL D., IONETE R.E., SANDRU C., IORDACHE A., CULEA M. Rom. J. Phys. 56, 1001, 2011.

17. SPRYNSKYY M., KOSOBUCKI P., KOWALKOWSKI T., BUSZEWSK B. Influence of clinoptilolite rock on chemical speciation of selected heavy metals in sewage sludge. Journal of Hazardous Materials. 149, 310, 2007.

18. JAHANTIGH M., Impact of Recycled Wastewater Irrigation on Soil Chemical Properties in an Arid Region. Pak J Biol Sci. 11 (18), 2264, 2008.

19. MOJIRI A., Effects of Municipal Wastewater on Physical and Chemical Properties of Saline Soil. J. Biol. Environ. Sci. 5 (14), 71, 2011. 
20. PUTAKA R., DAMODHRAM T. Determination of Heavy Metals in Industrial Waste Waters of Tirupati Region, Andhra Pradesh. International Journal of Science and Research. 5 (5), 2452, 2016.

21. VANITA C., PIAR C., AVINASH N., KAUR K.J., PAKADE B.Y. Evaluation of heavy metals and its genotoxicity in Agricultural soil of Amritsar, Punjab, India. Int. J. Res. of Chem. Environ. 4, 20, 2014.

22. MATTHEWS A.C.O., KAKULU S. Impact of mining and agriculture on heavy metal levels in environmental samples in Okehi local government area of Kogi State, Int. J. Pure Appl. Sci. Technol. 12, 66, 2012.

23. ALINA L., ISIDORA R., ADINA B., LAȚO K., F. C. The Transfer Factor of Metals in Soil-Plant System. Research Journal of Agricultural Science. 44 (3), 2012.

24. OLANESCUL G., GAMENT E., DUMITRU M. Fitoextracția solurilor poluate $\mathrm{Cu}$ metale grele, Lucrări Ștințifice Facultatea de Agricultură Bucureşti, seria A, I. 359, 2007.

25. RANGNEKAR S.S., SAHU S.K., PANDIT G.G., GAIKWAD V.B. Accumulation and Translocation of Nickel and Cobalt in Nutritionally important Indian vegetables grown in artificially contaminated soil of Mumbai, India. Re-search Journal of Agricultural and Forest Sciences. 1, $15,2013 b$.

26. TONY B. Collecting and preserving plant specimens, a manual. Department of Science, Information Technology and Innovation. 2 (1), 2016.

27. AUSTRALIAN NATIONAL BOTANIC GARDENS. Plant Collection Procedures and Specimen Preservation. Australian Government, Canberra. 2016.

28. ZHANG X., CHEN D., ZHONG T., ZHANG X., CHENG M., LI X. Assessment of cadmium (CD) concentration in arable soil in China. Environ. Sci. Pollut. Res. 22, 4932, 2015.

29. MARIN S., LACRIMOARA S., CECILIA R. Evaluation of performance parameters for trace elements analysis in perennial plants using ICP-OES Technique senila Marini. J. Plant Develop. 18, 87, 2011.

30. MILESTONE SRL-Helping chemistry www. Milestonesrl. com-Rev 0/, 2011.

31. GAUDINO S., GALAS C., BELLI M., BARBIZZI S., ZORZI P., JACIMOVIC R., JERAN Z., PATI A., SANSONE U. The role of different soil sample digestion methods on trace elements analysis: a comparison MS and INAA measurement results. Accreditation and Quality Assurance. 12 (2), 84, 2007.

32. TUZEN M. Determination of heavy metals in soil, mushroom and plant samples by atomic absorption spectrometry. Microchemical Journal. 74 (3), 289, 2003.
33. BIGDELI M., SEILSEPOUR M. Investigation of Metals Accumulation in Some Vegetables Irrigated with Wastewater in Shahre Rey-Iran and Toxicological Implications. American-Eurasian J Agric \& Environ Sci. 4, 86, 2008.

34. MICO C., PERIS M., SANCHEZ J., RECATALA L. Heavy metal content of agricultural soils in a Mediterranean semiarid area: The Segura River Valley (Alicante, Spain). Span. J Agric Res. 4, 363, 2006.

35. FAO/WHO. Joint FAO/WHO Food Standards Programme Codex Committee on Contaminants In Foods. 2011.

36. LING-ZHI L., ZONG-QIANG G., ZHANG Y.L., PEI-JUN L. Growth, cadmium accumulation and physiology of marigold (Tagetes erecta L.) as affected by arbuscular mycorrhizal fungi. Pedosphere. 21 (3), 319, 2011.

37. ZAIGHAM H., ZUBAIR A., KHALID U.K., MAZHAR I., RIZWAN U.K., JABAR Z.K.K. Civic Pollution and Its Effect on Water Quality of River Toi at District Kohat, NWFP. Research Journal of Environmental and Earth Sciences. 4 (5), 2012.

38. SHANQIAN W., TAIYANG Z., DONGMEI C., XIUYING Z. Spatial Distribution of Mercury $(\mathrm{Hg})$ Concentration in Agricultural Soil and Its Risk Assessment on Food Safety in China. Sustainability. 8, 795, 2016.

39. BRIAN J.A. Bioavailability of elements in soil; the University of Reading, Elsevier Inc. 2005.

40. YANG Q., ZENG X., ZENG J., KUANG W., LIU D. Heavy Metal Enrichment and Bioaccumulation of Equisetum ramosissimum in $\mathrm{Pb}-\mathrm{Zn}$ Tailings. Academia Journal of Scientific Research. 4 (10), 368, 2016.

41. GAILE Z.V., KLAVINS M. Transfer of Metals in Food Chain: An Example with Copper and Lettuce. Environmental and Climate Technologies. 21, 2012.

42. NESTA B.S., SHOUTA M.M.N., OSEI A., YOSHINORI I., JULIUS N.F., ELVIS B., HAZUKI M., MAYMI I. Accumulation of Heavy Metals and Metalloid in Foodstuffs from Agricultural Soils around Tarkwa Area in Ghana, and Associated Human Health Risks. Int J Environ Res Public Health. 12 (8), 8811, 2015.

43. ERAKHRUMEN A., AGBONTALOR A. Review Phytoremediation: an environmentally sound technology for pollution prevention, control and remediation in developing countries. Educational Research and Review. 2 (7), 151, 2007.

44. MORENO F.N., ANDERSON C.W.N., STEWART R.B., and ROBINSON B.H. Phytofiltration of mercurycontaminated water: Volatilisation and plant-accumulation aspects. Environmental and Experimental Botany. 62 (1), 78, 2008. 